Wayne State University

DigitalCommons@WayneState

Communication Faculty Research Publications

Communication

$1-1-2013$

\title{
A Propaganda Model Case Study of ABC Primetime 'North Korea: Inside the Shadows'
}

Sherri L. Ter Molen

Wayne State University

\section{Recommended Citation}

Ter Molen, Sherri L. (2013). A propaganda model case study of ABC primetime 'North Korea: Inside the shadows'. In R. Frank, J. E. Hoare, P. Köllner, \& S. Pares (Eds.), Korea 2013: Politics, Economy, and Society (pp. 241-266).

Available at: http://digitalcommons.wayne.edu/commfrp/7

This Book Chapter is brought to you for free and open access by the Communication at DigitalCommons@WayneState. It has been accepted for inclusion in Communication Faculty Research Publications by an authorized administrator of DigitalCommons@WayneState. 
NOTICE IN COMPLIANCE WITH PUBLISHER POLICY: This is a reconstructed and formatted version of a chapter originally published in Korea 2013: Politics, Economy, and Society, 2013, 241-266. Copyright (c) 2013 Brill publishing, Leiden, Netherlands. Archived by permission. 


\title{
A Propaganda Model Case Study of $A B C$ Primetime 'North Korea: Inside the Shadows'
}

\author{
KOREA 2013: POLITICS, ECONOMY, AND SOCIETY, Rüdiger \\ Frank, James E. Hoare, Patrick Köllner, and Susan Pares, \\ Editors
}

\section{Sherri L. Ter Molen ${ }^{1}$}

\begin{abstract}
In 2006, Diane Sawyer became the first American journalist to broadcast live from inside North Korea. Her trip ended with an hour-long special programme scrutinising life in what she considers possibly 'the most dangerous flashpoint on Earth' (Sawyer 2006). The threat Sawyer actually presents, however, is not that of a nuclear-armed country but of a country whose regime, despite the will of the people, refuses to be a major market for US consumer goods. Applying Herman and Chomsky's propaganda model of media operations, I conduct a discourse analysis of the textual and visual symbols Sawyer uses in illustrating and evaluating the country's quality of life in $A B C$ Primetime 'North Korea: Inside the Shadows'. I conclude that Sawyer is unable to overcome her ethnocentric worldview, and therefore, North Korea is unable to emerge from the shadows.
\end{abstract}

Keywords North Korea, propaganda model, propaganda analysis, Diane Sawyer, broadcast journalism, ABC Television Network

\section{Introduction}

In 2006, Diane Sawyer became the first American journalist to broadcast live from inside the Democratic People's Republic of Korea (DPRK). ${ }^{2}$ Her historic trip ended with an hourlong special show scrutinising life in what

\footnotetext{
${ }^{1}$ The author would like to thank Barbara Speicher (DePaul University), Michelle Millard (Wayne State University), and Bekki Chapman (media professional) for their helpful feedback.

${ }^{2}$ I use DPRK and North Korea interchangeably. When referring to its southern neighbour, I use Republic of Korea (ROK) or South Korea.
} 
she considers possibly 'the most dangerous flashpoint on Earth' (ABC News 2012; Sawyer 2006). Yet despite her deployment of fear (Klaehn 2009) in the first few minutes of the report regarding the country's military might and nuclear power, she spends much of the programme criticising the North Korean way of life and heralding evidence of a US cultural invasion in this supposed 'hermetically sealed nation' (Sawyer 2006).

Applying Herman and Chomsky's (2002) propaganda model of media operations (PM), I conduct a discourse analysis of the textual and visual symbols Sawyer uses in illustrating and evaluating the DPRK's quality of life in $A B C$ Primetime 'North Korea: Inside the Shadows'. The US Department of State reports that the United States (US) exported only \$5.8 million ${ }^{3}$ in goods to communist North Korea in 2005, the year before Sawyer's report (US Census Bureau n.d. a) compared to nearly \$27.6 billion in goods exported to its fellow capitalist country of South Korea during the same period (US Census Bureau n.d. b). Against this background, I specifically examine Sawyer's reliance on the capitalistic value of consumption as her primary measure of the standard of living and level of freedom in the DPRK to understand 'how ideological and communicative power connect with economic, political and social power' (Klaehn 2009: 43).

News frames are ways of organising information to allow journalists and the public to make sense of perceived realities (Lim and Seo 2009: 205); yet Sawyer, an employee of The Walt Disney Company, one of America's largest media conglomerates, does not take up an opportunity to provide an alternative to the axis of evil news frames that have painted the DPRK as a military threat, a human rights violator, and a nation at odds with the US since the state of the union address the then president, George W. Bush, gave in January 2002 (Lim and Seo 2009). At one point, for example, Sawyer leads an English class at a foreign languages high school in a chorus of 'Do Re Mi' from the American film, The Sound of Music, as if this is evidence North Koreans crave the (market) freedoms they are denied. I challenge Sawyer's ethnocentric reinforcement of these negative news frames and question the power structures that prevent her from separating the people and their culture from the hostile political relationship between the DPRK and the US.

${ }^{3}$ All monetary amounts are presented in US dollars. 


\section{A Propaganda Model Case Study}

\section{Review of the Literature}

\subsection{Framing North Korea in the US media}

Cumings (2004: 15) contends that the media situate the US as a benevolent nation provoked by the DPRK's determination to acquire 'weapons of mass destruction'. From a framing perspective, the positions of these two adversaries in the media are created by arranging fragments of a 'perceived reality' to promote a narrative that supports a particular view (Entman 2007: 164). There is a large body of work on media framing to support this broad understanding, but there are relatively few studies that attempt to explain how North Korea specifically is constructed in the US media.

Generally, these few framing studies have contended that the DPRK is an enemy of the US, one that should be approached carefully. Lim and Seo (2009), for example, conducted a content analysis of US government policy statements in the New York Times from 29 January through to 31 May 2002 during the four-month period immediately following. Bush's evocation of an 'axis of evil' in his state of the union address, and found that the US government's official hostile position on the DPRK was reinforced through the newspaper's framing. In contrast, the New York Times between December 2002 and February 2003 used framing to promote diplomatic rather than military engagement with North Korea, and US public opinion mirrored this framing (Khang 2004). In the two weeks immediately following the DPRK's first nuclear test in 2006, however, USA Today presented the option of military engagement with North Korea in addition to diplomacy and presented it with greater force than did peer publications in China, Japan, Russia or South Korea (Chung, Lessman, and Fan 2008). The Associated Press also framed the DPRK as a threat in the larger context of the war on terror in October of that year (Dai and Hyun 2010). The evolution of these news frames from diplomacy to the possibility of armed conflict was reflected in public opinion polls, which indicated that between 2000 and 2007 the US public increasingly viewed North Korea as a threat (Kim et al. 2008), demonstrating that news frames do indeed shape public opinion. Yet despite the fact these studies have found that the US government, the media and the public identify the DPRK as an enemy state, the authors of these studies do not necessarily label the North Korea news frames as negative. 
Choi (2006 and 2010), however, used framing analysis to examine newspaper articles that ran within a two-year window from January 2001 through to December 2002 in the New York Times and the Washington Post. He concluded that there were 20-times the number of negative North Korea news frames in the New York Times and 11-times the number of such news frames in the Washington Post as positive news frames about the country in either newspaper. He made his value judgment on the basis of his findings that the newspapers framed North Korea as an evil enemy and a terrorist state. It would certainly be difficult to argue that these news frames could be considered positive, and it is permissible to apply Choi's value judgment to the other news frames that have emerged in the North Korea framing research. It might even be permitted to go one step further and to identify these negative North Korea news frames as propaganda.

\subsection{Propaganda}

Giroux (2008: 126) states that 'propaganda is generally used to misrepresent information, promote biased knowledge, or produce a view of politics that appears beyond question or critical engagement.' Yet despite this definition, scholars have not generally labelled the framing of North Korea in US media as such. In contrast, however, Jang (2008) conducted a content analysis of editorials produced by the Korean Central News Agency (KCNA) in the DPRK from August 2003 to September 2007 with a view to examining the news frames surrounding the Six Party Talks that took place during that four-year period. Not only did he conclude that the frames positioned the US as a 'diplomatic and economic concern', but he also connected this framing to the accusation 'that North Korea's media have historically been a propaganda tool of the ruling political party, the leader, and the government' (Jang 2008: 16).

It seems that there is a double standard here. One example may be found in an article that appeared in the New York Times in February 2013, which was keen to point out that a DPRK YouTube video showing New York engulfed in flames was 'North Korean propaganda' (Choe 2013). Yet, articles that also ran in the New York Times in 2004 failed to accuse the film, Team America: World Police, of being American propaganda despite the newspaper's reporting that 'Alec Baldwin...emerges as a villain almost as evil as Kim Jong Il' (emphasis added) (Waxman 2004: 2, 1) and despite its 


\section{A Propaganda Model Case Study}

reporting that Kim Jung Il is portrayed as the mastermind behind 'a diabolical plot to arm global terrorists with weapons of mass destruction' (once again, emphasis added) (Scott 2004: E1).

Scholars and journalists might fail to recognise these double standards and biases as anti-North Korean propaganda because, as Herman and Chomsky (2002: 1) note, 'it is much more difficult to see a propaganda system at work where the media are private and formal censorship is absent.' However if Giroux (2008: 25) is correct that the media are largely tools of the elite who use them for targeted advertising, the promotion of antidemocratic ideologies that support corporate interests, and the goal of distracting the public from critical civic engagement with 'infortainment' such as celebrity scandals, it is exigent to consider the possibility that negative North Korea news frames in the US media are indeed propaganda and that those who present the view that the US is a righteous party to North Korea's aggressive provocations also benefit from it.

\section{Method}

The propaganda model offers a means for critiquing the mass media's power structures by focusing on the influence of economic power, which works to marginalise dissenting viewpoints in order to serve the interests of the dominant elite (Herman and Chomsky 2002: 2). The model is employed within the method of discourse analysis (Mullen 2009: 16), that is, the systematic inspection of the structures and functions of texts (van Dijk 1991: 108), and it assumes that when the media are under corporate rather than state control, programming and news coverage are influenced by a 'guided market system' (Herman and Chomsky 2002: 1x; Mullen 2009: 13).

Within this framework, media in capitalist societies are constrained by five filters: (1) size, ownership, and profit orientation; (2) the advertising licence to do business; (3) sourcing mass media news; (4) flak and the enforcers; (5) anti-communism as a control mechanism (Herman and Chomsky 2002: 5-31). These filters work together to 'mobilize and divert, promote and suppress, legitimize and endorse' media discourses to support the needs of those in power (Klaehn 2002: 152).

The PM is controversial, however, and critics argue that any 
accusation that thousands of journalists toe a single 'party line' assumes conspiracy (Herman 2000: 104). Proponents of the model repudiate this criticism and argue that the decisions made by journalists and other media producers to include some stories and viewpoints and to exclude others often constitute 'unconscious hegemony' (Klaehn 2002: 148-49), meaning that the tenets of domination are embedded deeply in 'a system so powerful as to be internalized largely without awareness' (Herman and Chomsky 2002: 302). They argue that this is possible because the mass media tend to hire like-minded individuals and because employees who do not initially share these ideologies adopt them through socialization processes (Herman and Chomsky 2002: 304).

Other criticisms of the PM include the accusation that it is deterministic, but Herman and Chomsky counter that all models are. They argue further that if a model can make predictions or if it can lead to understanding, it proves its usefulness. Critics also dismiss the model on the grounds that it was designed during the Cold War and that communism is no longer relevant (Mullen 2009: 16-18). It is true that communism is perceived as less of a threat in today's world than when the PM was introduced. To take account of this change, the final filter has often been referred to in recent years as dominant ideology (Klaehn 2009: 45). Herman and Chomsky profess that the PM can be adapted for whatever threat to 'free market ideology' is salient at the time (Mullen 2009: 18), and Herman (2000: 111) believes it is actually more relevant in the post-Cold War era than when the PM was originally published in 1988. ${ }^{4}$ Of course, in the case of North Korea, communism is still relevant but within a post-Cold War context.

Because the PM is controversial, it is often excluded from debates over media bias (Herman 2000: 101). In those rare studies where media critics employ the PM, they generally do so in two ways. The first method is to compare the media coverage of two disparate events that occurred during the same historical period. The second is to examine the framing of a single historical event across the media by investigating its sources and analysing its content (Klaehn 2002: 168). The analysis deployed in this paper closely resembles the second method, though I examine a single media artefact instead of the framing of an event across multiple media. Cumings (2004: 101) recalls that after George W. Bush identified North

${ }^{4}$ For a discussion of further criticisms, see Mullen (2009). 


\section{A Propaganda Model Case Study}

Korea as part of his axis of evil, 'a supine American media fell in line with the administration's caricature of the crisis in Korea, instead of doing serious investigative reporting.' The purpose of this case study of $A B C$ Primetime 'North Korea: Inside the Shadows' is to investigate this claim. Sawyer may not always be accurate when describing North Korea, but times have changed. For instance, as of 2013, foreigners are allowed to carry their mobile phones into the country (NK Nerws 2013), but in 2006, Sawyer's team were required to leave their mobile devices at the airport. The experiences Sawyer relays are thus not necessarily representative of what is happening in the DPRK in 2013. A case study is meant to be descriptive of a particular artefact, but it can lead to 'the development of more general, nomothetic theories' (Babbie 2007). Sawyer visited Pyongyang in October 2006, just days after the DPRK conducted its first nuclear test. Now, in 2013, the US media have been ablaze with reports on North Korea's third nuclear test, and this would seem a relevant time to revisit her report. I have chosen to apply the PM, despite the criticisms of the model, because I believe that it might be an appropriate device for examining the economic, political and social power at work in this particular report and because I believe this analysis might also be able to demonstrate some of the strengths of the controversial model.

ABC Primetime 'North Korea: Inside the Shadows' was a one-hour programme when it was originally shown on 8 December 2006. It was the culmination of Sawyer's live reports from Pyongyang that aired during $A B C$ 's news programmes in October of that year (ABC News 2012; IMDb n.d.; Sawyer 2006). I watched the original broadcasts of the live reports and the $A B C$ Primetime special and subsequently reviewed a 41-minute commercial-free DVD of the programme 16 times for this analysis. In what follows, I apply each of Herman and Chomsky's filters (see above) to this video account of North Korean life, and deconstruct the visual and textual symbols presented by Sawyer as I ask the following research questions:

RQ1: How do economic, political and social power work to reinforce negative North Korea news frames?

RQ2: How do economic, political and social power work to obscure North Korean culture?

Cumings (2004: viii) describes North Korea as 'the country every American loves to hate'. Since previous studies have already found that the US media cultivate such views (e.g., Choi 2006 and 2010), it is 
important to decipher how these views are formed as well as to consider who benefits from their distribution.

\section{Analysis}

The first filter of the PM is size, ownership, and profit orientation. As Schiller (1989: 135) notes, the industries that manufacture culture and information 'have grown greatly in size, breadth, and productive capability in the years since World War II.' When Herman and Chomsky (2002) published their treatise on the influence of ownership on media content nearly 25 years ago, the broadcast industry in the US had only recently been deregulated, and two-thirds of the companies were still, in effect, family businesses, where originating family members still held high-level positions or retained a majority interest in stocks. By the midto-late 1980s, however, ABC had already been acquired by Capital Cities and was controlled by corporate officers and directors. A large media company for the time, $\mathrm{ABC}^{\prime}$ s revenue in 1986 was reported at $\$ 4.1$ million (Herman and Chomsky 2002: 6-9).

Today, ABC belongs to The Disney/ABC Television Group (Disney/ABC Television Group n.d.), a subsidiary that falls under the larger umbrella of The Walt Disney Company, which also includes Walt Disney Pictures, Pixar, ESPN, and a number of other brands. In 2011, the revenue of this media conglomerate topped $\$ 40.1$ billion (Free Press n.d.), and $\$ 4.9$ billion of this revenue was attributed to ABC alone (Steinberg 2012).

The consolidated corporate media set the agenda for the issues that are salient among the public (Giroux 2008: 24), and this makes the corporate voice 'the loudest in the land'. Because the purpose of corporations is to increase revenue (Schiller 1989: 4), this corporate voice primarily disseminates fiscally conservative ideologies including the breathless rhetoric of the global victory of free-market rationality' (Giroux 2008: 6). Corporations including media giants such as ABC employ free market activities to generate earnings and maximise profits.

The advertising licence to do business is the second PM filter, and $\mathrm{ABC}$, like other commercial networks, is financially dependent on advertising. $A B C$ Primetime earns the network 'millions of dollars in profits', and Sawyer, one of the highest-paid women in broadcast news, 


\section{A Propaganda Model Case Study}

has been credited with the ratings and financial success of the programme (Lovdahl n.d.). Sawyer joined ABC in 1989 after working for one of the company's competitors, CBS, for nine years. Prior to her broadcasting career, she served on the Nixon-Ford transition team and assisted former President Nixon with the writing of his memoirs (ABC News 2012).

Observing this programme through the lens of the first and second filters uncloaks the power structures that colour Sawyer's judgment when she labels North Korean lives as 'Spartan' 5 (Sawyer 2006). Sawyer emphasises the 'sober clothes' that usually lack American brand names. At the same time, she is quick to point out US cultural products when she sees them, particularly those that represent her own company's brands, such as a small plush Minnie Mouse in the home of a famous former North Korean figure-skating champion. She says: 'But throughout the country, we keep seeing something puzzling. There! On that mirror! Isn't that Minnie Mouse?' A few minutes later, she reminds the viewers of her visit to the English class at the foreign languages high school, and she seems pleased to point out that, although the students claim they have never seen an American movie, their favourite films are Toy Story, a Walt Disney Pictures/Pixar collaboration (Guggenheim and Lasseter 1995), and Shrek. Sawyer clearly believes the enjoyment of these two Hollywood animated films signals a greater desire for American cultural products, while also noting the students had 'no idea that they came from the enemy camp' (Sawyer 2006). Perhaps this comes as no surprise, since Sawyer has been so long interwoven into the circles of the dominant elite in the US that her orientation is also economic, validating Herman and Chomsky's claim that the mass media hire like-minded individuals (Herman and Chomsky 2002: 304).

The model's third filter is sourcing mass media news. Sawyer's surprise that the refrigerator in the former champion figure-skater's home is 'a typical American refrigerator' (Sawyer 2006) suggests that she had pre-conceived notions about what she expected to find (and not to find) when she visited North Korea. It is likely that the same negative news frames that shaped US public opinion also shaped Sawyer's expectations. Lim and Seo (2009: 213-19) found that the American people relied on the

5 This and following paragraphs contain many quotations from Sawyer's programme ABC Primetime 'North Korea: Inside the Shadows' (2006). Where it is clear that the phrases and sentences quoted are taken from her reportage, they have not been further attributed. 
news frames presented by the US government and the mass media, since other sources of information, such as direct contact with the DPRK, were scarce. Yet the experts who supplied the information used to construct these news frames may not have had much more direct contact with North Korea than any other American citizen, since, as Sawyer notes, the North Korean government representatives who accompanied her team at all times - the team's 'minders' - told them that there were only 300 foreigners in North Korea, a country of 23 million, during the time of their visit. ${ }^{6}$

In addition to the possible lack of direct contact, Chomsky identifies another potential cause of misinformation generated by the experts: money. He accuses the 'liberalintelligentsia' of participating in legitimising unconscious hegemony when they provide their expertise to the media, since their employers, usually universities, are often dependent on corporate donors (Klaehn 2009: 169-70). Objectivity was, at one time, the backbone of broadcast journalism in the US (Cushion 2012: 11), but since the Cold War, there has been a turn towards interpretive reporting, which emphasises causes and ideas rather than events (Applegate 2007: 5, 8). Even when the liberal intelligentsia do not feel constrained, journalists 'seem to govern both how the interview is conducted as well as how it is edited into the final news story' (Nylund 2003: 531), and these sound bites have been found to reinforce the status quo (Mason 2004).

Nevertheless, audiences expect the news media to be objective (Hackett 1984), and Sawyer does attempt to make her report appear balanced at times. She includes, for example, a sound bite offered by Donald P. Gregg, a former US ambassador to the ROK, who advocates greater dialogue between the DPRK and the US to increase understanding. Nonetheless, the majority of the academic and governmental sound bites Sawyer presents reinforce the pre-existing negative news frames, as when Dr Charles Armstrong, a professor of history at Columbia University, describes high-rise apartment buildings in Pyongyang that often do not have working elevators, running water, or consistent electricity. The positioning of the DPRK as a dialogue partner at odds with the US (Lim and Seo 2009) is reinforced with a carefully selected sound bite offered by

${ }^{6}$ Americans were able to travel to North Korea in 2006, but Sawyer does not indicate whether the North Koreans specified the number of Americans among the 300 foreigners they declared were in the country at the time. 


\section{A Propaganda Model Case Study}

Dr Meredith Jung-En Woo, who at the time was a professor of political science at the University of Michigan. She informs viewers that North Korea is 'run by a dead person' (Sawyer 2006). This is not quite accurate, but Kim Il Sung, the first leader of North Korea, who passed away in 1994, does retain the title of 'eternal president' (Sawyer 2006). Viewers experience this sound bite out of context and bookended with Sawyer's commentary, which shapes the overall narrative, and they are left to contemplate how the US, despite Donald Gregg's urgings, could possibly engage in increased dialogue with a ghost.

The reverence that North Koreans have for their leaders has traditionally elicited a response of mockery from US journalists. For example, a 2003 New York Times writer admitted he 'gleefully purchased a book with a stern photo of Kim Jung Il titled The Great Teacher of Journalists simply as a joke' (Kristof 2003: A27). Sawyer uses a copy of this same book in her report to illustrate the differences between North Korean journalism, which is controlled by the state, and American journalism, which she implies is free, but which Herman and Chomsky (2002) argue is controlled by the dominant elite. Yet Sawyer scoffs at North Korean propaganda without ever considering her views might also be shaped by America's own brand of propaganda. Case in point, on her way to Pyongyang on 'an old Soviet jet' (Sawyer 2006), she dismisses an article in the North Korean airline magazine that accuses the US of committing atrocities during the Korean War, despite substantial evidence to support such accusations, including testimony gathered during the No Gun Ri massacre investigation (see Hanley, Choe, and Mendoza 2001). In addition, she mocks the onboard announcement that heralds her 'arrival in a state, which is also a kind of state of mind' (Sawyer 2006). On all probability backed by the same governmental and media experts that inform the American public on the topic of North Korea, Sawyer's views had already been solidified before she arrived in the DPRK.

The fourth filter of the PM is flak and the enforcers. Flak can take on many forms including letters, telephone calls, or petitions that rebuke the media for something they have said or done. These communications can come from the public or from a powerful entity such as the White House (Herman and Chomsky 2002: 26), but there is no evidence to indicate that flak was ever a threat in the case of $A B C$ Primetime 'North Korea: Inside the Shadows'. Blinded by the ideologies of the market system, Sawyer does not 
challenge the negative news frames that had preceded her visit. In fact, she reinforces them, which is fortunate for her, $\mathrm{ABC}$, and $A B C$ Primetime's advertisers since, dating back to the McCarthy era, broadcasters judged as 'insufficiently anti-communist' have been chastised and subject to product boycotts by the public (Herman and Chomsky: 26, 29).

In the case of this particular study, the fifth and final filter of the PM, anticommunism as a control mechanism, applies as the dominant ideology. Anti-communism and pro-capitalism may not be the only ideologies at play, but Sawyer's repeated emphasis on economic differences provides evidence to this claim. Time and again, Sawyer points out the disparity of wealth and material accumulation between the middle and elite classes of North Korea and America. Of the family of the former figure-skating champion, she says, 'They live in three rooms, small by Western standards, about 700 square feet [65 sq m]', yet Pyongyang is the largest city in the DPRK. In America's largest city, New York, the average size of a one-bedroom ${ }^{7}$ apartment is a comparable $750 \mathrm{sq} \mathrm{ft}[69.6$ sq m] (Apartments.com 2012; Nakedapartments n.d.). Sawyer does not live in one of these average New York City apartments, however. At the time she visited this North Korean home in 2006, she and her husband were living in a '12-room, full-floor apartment at 1030 Fifth Avenue' in New York City (Abelson 2008; Gaines 2005), and the couple also owned an estate on Martha's Vineyard in Massachusetts (CelebrityDetective n.d.). Sawyer's understandings of what constitutes the American standard might thus be slightly skewed. On another occasion, in a factory, Sawyer asks a young woman how much money she earns and explains: 'She confides she is paid 2,500 won a month, the equivalent of $\$ 20.00$, or, in the US, four lattes at Starbucks.' The young woman, however, says that $\$ 20.00$ a month 'is more than enough to live on' (Sawyer 2006), and perhaps in Pyongyang it is.

Sawyer, whose annual salary at the time was $\$ 12$ million, cannot fathom a society in which $\$ 20.00$ a month could be enough. Yet throughout the programme she implies that it is the North Korean people, rather than she, who have been brainwashed. When one woman on the street denounces the US while holding Sawyer's hand, Sawyer responds by boasting that the US is 'a very rich country, lots of food, lots of medicine, lots of opportunity for little children', implying that the DPRK

${ }^{7}$ A one-bedroom apartment generally has one bathroom, a kitchen and a living area. 


\section{A Propaganda Model Case Study}

does not possess any of these resources. However, this North Korean woman is not impressed with America's abundance and responds: ' $\mathrm{I}$ 'm not concerned about how Americans live their lives. I just want Americans not to meddle in our Korean people's affairs' (Sawyer 2006). This woman's priorities diverge so far from Sawyer's that Sawyer does not appear to comprehend that her interlocutor may be just as personally invested in the ideology of the North Korean state as Sawyer is invested in the ideology of the market-driven economy and the profit-driven structure of The Walt Disney Company.

\section{Discussion}

As Giroux (2008: 7) expounds, '[m]oney, profits, and fear have become powerful ideological elements in arguing for opening up new markets and closing down the possibility of dissent at home', and ABC Primetime 'North Korea: Inside the Shadows' provides ample evidence to support this view. Looking at this report through the five filters of the PM, I have pointed to the power structures that induce Sawyer to rely on the capitalistic value of consumption as her primary measure of the standard of living and level of freedom in North Korea, and have interpreted the meanings of the textual and visual symbols embedded within the programme.

\subsection{Reinforcing negative North Korea news frames}

Turning to the two research questions I outlined above (Section 3), the first asks how economic, political and social power work to reinforce negative North Korea news frames. Sawyer invokes fear by depicting Kim Jong Il as 'a mysterious leader who has spread fear throughout the world by unleashing a nuclear explosion' (Sawyer 2006). She does not linger on the country's build-up of nuclear capabilities, however. What concerns her is how much longer North Korea can 'hold out against the barbarians at the gate', and she does not mean an invading US military force. What she actually means is a US cultural invasion, and she implies that 'bolting the door against a world of personal and political freedom, exuberant with PlayStations, paparazzi, and personal consumption' is a futile effort. She accompanies this indirect assertion with footage of a young, chubby South Korean man holding a giant soft serve ice cream cone as a reminder that US-led capitalism has already succeeded in the South. 
Sawyer is preoccupied with the fact that the DPRK has a lavish military but that civilians are deprived of stockpiles of luxury goods. After learning that a manager has barred the $A B C$ crew from filming inside a department store, an irritated member of Sawyer's team proclaims: 'This is going to be part of our story. If that's what he wants America to see, that's what we'll show. Come on. Let's go' (Sawyer 2006). The crew is also barred from filming in a grocery store, and Sawyer is shown walking away frustrated. Together, these scenes imply the crew was forbidden to film because the North Koreans did not want Americans to see how little merchandise there was available to buy. Sawyer supports this deprivation narrative further while exploring the home of the former champion figureskater. Looking at the small closet, she ponders, 'Imagine that for most American teens'; and is further astounded by the meagre inventory in the refrigerator. 'There were some eggs, some bottled water, but not the grocery excess you see a lot in the United States', she recalls. 'Of course, in the fridge I saw kimchi, the famous Korean pickled cabbage'.

Kimchi serves as a segue for her to relay yet another story about how North Koreans have so much less than Americans. The minders also forbid Sawyer and her team from taping a home preparation of this national dish, and irritated, she alleges, 'Perhaps they're concerned it will look like that's all there is to eat' (Sawyer 2006). Noting that the military gets fed first in North Korea, she reminds the audience of the famine that took place a decade earlier in the 1990s, during which, the US State Department estimates, a million North Koreans, primarily civilians, including children, died of starvation. ${ }^{8}$ She notes the absence of overweight people on the streets and cites a statistic that North Koreans are four inches shorter than their South Korean counterparts, a figure evidently held to be accounted for by decades of food shortages. She boasts, 'At our hotel, the food is plentiful, but only foreigners can afford this. A single entrée would probably take the entire month's salary of a factory worker.' With their overflowing closets, full bellies, and hoards of money, Americans and their South Korean allies, Sawyer signals, are much better off than their communist rivals.

\footnotetext{
${ }^{8}$ Sawyer (2006) does not identify her State Department source, but one State Department report from 2003 estimated as many as one to two million North Koreans died as a result of the famine (Manyin and June 2003). Cumings (2004: 178), however, argues that the estimated number of North Korean famine victims ranges from 500,000 to 2 million.
} 


\section{A Propaganda Model Case Study}

By equating 'consumption' with 'personal and political freedom' (Sawyer 2006), economic, political and social power converge to create a narrative that suggests the opening up of the North Korean market to US consumer products would free the people from oppression. Sawyer reinforces negative news frames by intermingling footage of North Korean tanks and starving children with images of an empty restaurant and commentary about the deficiency of brand-name clothes, revisiting here the old 'instrument of anticommunism' which, as Schiller (1989: 14) has argued, has proven in the past to be quite effective in drumming up fears of instability and a lack of prosperity. This 'culture of fear' (Giroux 2008: 53), which is perpetuated by the US media, summons up public support for any tactics the dominant elite may choose to employ as they hope to gain full access to the North Korean market.

\subsection{Obscuring the North Korean Culture}

The second research question asks how economic, political and social power work to obscure North Korean culture. Sawyer visits monuments to leaders of North Korea and meets a select number of military officials, but she spends much of her report interviewing Pyongyang residents in a park, visiting a bowling alley, and touring a film studio where she meets a North Korean film star, Pak Mi Hyang. Yet, instead of asking questions about the North Korean people and their way of life, most of her questions seem to seek testimony to support an assumption that North Koreans want to live like Americans.

She visits a beauty salon, for example, where she asks a young woman to look through the pages of a colourful American fashion magazine filled with flamboyant styles. The woman seems uninterested and tells her, 'We like to dress neatly in our own way' (Sawyer 2006). North Korean salons generally offer a range of 'recommended hair styles', and in 2005, the year before Sawyer's visit, the government had implemented a campaign aimed at men entitled 'Let us trim our hair in accordance with Socialist lifestyle' (NK Nerws, 2011). Whether Sawyer knows this or not, she does not accept the young woman's response as her own, and narrates that, after she and her crew had returned to New York, their translator, to use Sawyer's term, told them that another woman in the background actually instructed the young woman to say. Sawyer also asks this same young woman if she would want blond hair. The woman 
responds, 'We prefer the traditional Asian black hair' (Sawyer 2006). Once again, Sawyer, who has blond hair, cannot imagine that this woman would reject this hair colour of her own accord, and she dismisses the woman's preference as a sign that she has been brainwashed. 'And remember, it's not just style', Sawyer warns in regard to the North Korean woman's preference for her own hair colour. 'It's a kind of pride in racial purity.' In fact, each time a North Korean offers her or his perspective, Sawyer's words and/or tone suggest that she discounts their views and opinions. She does not seem to consider the possibility that her question might in itself be racist or that her perceptions of beauty might be steeped in her own culture or ethnocentrism.

Still in the beauty salon, Sawyer asks if a customer likes curly hair. The answer is somewhat obvious, since the woman has curly hair, but the interpreter responds, 'She doesn't like curly hair' (Sawyer 2006). Confused, Sawyer questions, 'She doesn't? Why is her hair curly?' Finally realising that the interpreter does not understand her question, she says, 'No, curly...curly', as she makes a curling gesture with her fingers while releasing an exasperated laugh. Although Sawyer is unapologetic that she does not speak Korean and awkwardly mispronounces the couple of Korean words she tries to say, she exhibits little patience for her North Korean interpreter when he does not understand. On the other hand, she takes the presence of the English phrase 'LOVE IS IN FAMILY' embroidered on a pillow in the home of the former figure-skater to mean that the North Korean people value the English language and desire American culture. After the students in the English class at the foreign languages high school reveal that although they were not aware the films were American, they had actually seen at least two Hollywood films, Sawyer narrates: 'So we decided to try one more test, a song almost every child can sing around the world'. She then leads the class in a rendition of 'Do Re Mi' from The Sound of Music, implying that the students' knowledge of the song proves that North Koreans crave American culture and its (market) freedoms (Sawyer 2006). If she had inquired how they knew these films and soundtracks, she might have learned that English language students in the DPRK are shown American and English films for language study (Lloyd-Roberts 2010).

Sawyer continuously notes that the government restricts knowledge of and contact with the outside world. She asks a 20-year-old university 


\section{A Propaganda Model Case Study}

student studying to be a nuclear scientist if she knows about 'America's most common college tool, Google' (Sawyer 2006). In a country where she claims the 'Internet is forbidden', knowledge of Google would, of course, be useless. What Sawyer does not seem to know, though she shows a computer that rejects the abcnews.com address, is that an Intranet has operated within the DPRK since sometime around 2001 and that some North Koreans have access to the Internet, even though such access is 'severely restrained by politics' (Cumings 2004: 191). The university student does not know of Google, but she promises to study about it. Sawyer cites former Secretary of State Madeleine Albright's visit to the DPRK in 2000, during which Kim Jung Il asked for her email address, but is still amused when an 84-year-old Korean War hero offers her the Hotmail email addresses of his children who live in the US.

Sawyer is so convinced that the North Koreans actually want to look, speak and live like Americans that she never seriously considers that there may be some truth to the North Korean government's claim that 'its people wouldn't want consumerism if you gave it to them' (Sawyer 2006). The elderly Korean War hero, who had once lived in South Korea, criticises capitalism because, within this system, 'money comes first. It's survival of the fittest'. Showing a map of the Korean peninsula at night with the northern half engulfed in darkness, Sawyer totes the bright lights of the southern portion as proof of capitalism's superiority, and she spends the majority of the report, at the expense of her journalistic objectivity, seeking evidence to support the notion that the North Korean people have consumerist desires. According to her assessment, the only thing standing between the North Korean people and the free market system is the government of the DPRK.

Examining $A B C$ Primetime 'North Korea: Inside the Shadows' through the five filters of the PM, reveals how economic, political and social power shape Sawyer's narrative in a way that advances the interests of US corporations such as her employer, The Walt Disney Company. The company would certainly like to line the shelves of the North Korean grocery and department stores with its products. Even when she witnesses what she considers to be an all-too-perfect performance by preschoolers, she compares the young musicians to 'a living version of Disney's "It's a Small World"' (Sawyer 2006). The ideological clash between North Korea and the US distracts Sawyer, and she squanders her 
opportunity to discover a different facet of North Korean culture to present to the American people.

\subsection{Evaluation of the propaganda model}

Like 'the deafening absence of any contrary argument' that presents a different view of North Korea (Cumings 2004: viii), studies that both argue for and demonstrate the usefulness of the PM are few and far between. Perhaps as Herman and Chomsky acknowledge, the controversial model is not applicable in every situation, but, in this case study of ABC Primetime 'North Korea: Inside the Shadows', the PM, as predicted by Mullen (2009), has demonstrated its resilience and has led to understanding. Taking into consideration Giroux's definition of propaganda, which posits that biased or misrepresented information is disseminated to promote a particular view that 'appears beyond question of critical engagement' (Giroux 2008: 126), the five filters of the PM have revealed why Sawyer does not seem to question the pre-existing negative North Korea news frames and how she participates in their reproduction.

Sawyer is constrained because she works for a division of The Walt Disney Company, an extremely wealthy business. Herman and Chomsky (2002: xl) explain that

the same underlying power sources that own the media and fund them as advertisers, that serve as primary definers of the news, and that produce flak and proper-thinking experts, also play a key role in fixing basic principles and the dominant ideologies.

It would not be in The Walt Disney Company's best interest, or in the best interests of their profit-driven advertisers who pay for $A B C^{\prime} s$ programming, to challenge the pre-existing negative North Korea news frames. By viewing North Korea as a military threat, the US news media keep in line with NSC 68, a 1950 National Security Council report that guided US foreign policy during and after the Cold War. The document states that it is the US objective to 'foster a world environment in which the American system can survive and flourish' (Layne and Schwartz 1993: 5). As Cumings (1999: 289) points out, 'military power was of course important in constructing a liberal order', and positioning countries such as the DPRK as a military threat still keeps allies financially dependent on the US. Some companies such as $3 \mathrm{M}$ and The Dow Chemical Company may even also benefit from this impending threat, since they manufacture 


\section{A Propaganda Model Case Study}

military products in addition to the consumer products they advertise on broadcast television networks such as ABC.

The negative news frame that presents the DPRK as a human rights violator also serves The Walt Disney Company and its advertisers because it juxtaposes the unipolar pre-eminence and comprehensive economic advantage that the United States now enjoys' (Cumings 1999: 271) with 'the vanguard of the anti-imperial, anti-American rejectionist front' (ibid.: 279). Sawyer recalls the food shortages of the 1990s and condemns the gulags, but she focuses much more of her attention on the lack of consumer goods available as well on as the modest possessions of the North Koreans she meets. In neoliberal societies such as the US, the free markets are equated with democracy (Harvey 2010: 7), and Sawyer pulls at the American public's heartstrings when she implies that the US could free the North Koreans from oppression simply by exporting its consumer goods into the country. In October 2006, the same month in which the DPRK conducted its first nuclear test and in which Diane Sawyer travelled to Pyongyang, a CNN poll found that 60 percent of Americans thought that the conflict with North Korea 'could be resolved economically and diplomatically' (Bowman and Rugg 2013). If and when North Korea opens its markets, it may benefit The Walt Disney Company, which will seek to flood the DPRK with its media products and branded merchandise, even if it may find that Chinese, Japanese and South Korean goods are in there ahead of it.

As Cuming (2004: xiii) states, '[i]n human rights circles, the easiest thing has always been to look one way and condemn the communists', and reinforcing the negative news frame that postures North Korea as a dialogue partner at odds with the US (see Lim and Seo 2009), rallies the public behind the belief that the US is the more righteous of the two parties. Sawyer suggests that the DPRK should reform to the American brand of neoliberal capitalism without ever presenting the idea that the US could meet North Korea part way, let alone reform to the North Korean brand of chuch'e socialism. Clearly, chuch'e socialism would be detrimental to The Walt Disney Company, and in the eyes of profitdriven media outlets and advertisers, capitalism cannot be negotiated. Yet despite North Korean markets generally being closed to US media and consumer goods, ABC may still be able to turn a profit with the help of the DPRK because, as the economic and military standoffs become routine, 
audiences may tune in, raising Nielsen ratings and revenues that could translate to millions of dollars (see Herman and Chomsky 2002: 16)

In short, this analysis indicates that $A B C$ Primetime 'North Korea: Inside the Shadows' constitutes propaganda as defined by Giroux. The key now is to embrace this finding while considering its ramifications as well as alternative approaches for the future.

\section{Implications and Recommendations}

General Ri Chan Bok, who for more than four decades has been in charge of the Korean People's Army's troops stationed at the Demilitarised Zone, asks why the US president continuously insults his country. '[The United States] provoked us by calling us the Axis of Evil', he retorts. 'These kinds of malicious words all came from the United States...They all came from the lips of President Bush. Please tell him to stop telling these lies' (Sawyer 2006). By reinforcing the negative news frames that have saturated the US media since George W. Bush made his accusation, Sawyer adds insult to injury.

Cumings (2004: 47) blames the US media, which he maintains are 'almost bereft of good investigative reporters', of obscuring the nature of the conflict between the DPRK and the US, and he contends that North Korea not only wants diplomatic engagement but actually wants the US to remain involved in peninsular issues overall. He even imagines a time in which 'Americans will begin to enjoy touring this beautiful Hermit Kingdom and meeting its unknown but warm, proud, and dignified people' (ibid.: $\mathrm{x}$ ). This is a very different story to the one Sawyer presents when she promises 'to look behind the mask, the giant army, the fierce isolation, the strange conformity' of a country she insists is 'repeatedly celebrating itself' (Sawyer 2006).

Instead of conducting in-depth investigative reporting, as predicted by the PM Sawyer selects sound bites provided by the cheaper option of academic and governmental experts who support her preconceived notions. Sawyer explains, for example, that the Pyongyang subway tunnels double as bomb shelters to protect North Korean citizens during possible American attacks. She also describes the DPRK's demonstrations around the time of its first nuclear test in 2006. 'We saw the terrifying torch-lit processions,' she reminds, 'threatening banners....' This is 


\section{A Propaganda Model Case Study}

followed by a sound bite supplied by Dr Roy Richard Grinker, a professor of anthropology at George Washington University. 'If we look at North Korea from our perspective, yeah, they can look pretty crazy', he remarks. 'But if we look at the world from their perspective, what they're doing makes sense.' Sawyer continues:

What seems paranoid to the West, seems prudent to North Koreans. The Korean nation has fought back more than 900 invasions over the past two millennia. They see the US potentially as 901 (Sawyer 2006).

Grinker's sound bite reinforces Sawyer's general narrative that posits North Korean behaviour as absurd since she does not place it within the context of any possible wrongdoings committed by the US, which might have led to North Korea's justified fear of American attacks. These wrongdoings might include, for example, the occupation of the territory south of the 38th parallel for several years beginning in 1945 or the unloading of '866,914 gallons of napalm' on both soldiers and civilians across the Korean peninsula from June to late October in 1950 during the early stages of the Korean War (Cumings 2004: ix, 19). As previously noted, a former US ambassador, Donald P. Gregg, seems to recognise that the North Korean perspective is rooted in the past, and he offers a hopeful solution:

They have been fed this diet of anti-Americanism, and so they have antiAmerican feelings. We need to change their diet. We need to talk to them more, so they will understand us better. And in the process, we will understand them better (Sawyer 2006).

Perhaps it is time to change the American people's diet as well with in-depth investigative reporting that allows academic and governmental experts as well as the North Korean people greater space in which to present alternative views that challenge the salient negative North Korea news frames. Now might be the time to dismantle anti-North Korean feelings and to promote real prolonged diplomatic engagement with this country through the US media so that both countries can understand and appreciate each other better.

\section{Conclusion}

The title ABC Primetime 'North Korea: Inside the Shadows' conveys fear since shadows contain the dangerous unknown. In this discourse analysis in 
which I have applied Herman and Chomsky's propaganda model, or PM, I have questioned how economic, political and social power work to reinforce negative North Korea news frames and to obscure North Korean culture. I have also illustrated that these powers converge to create media discourses that are bound to the interests of the dominant elite and 'shaped by market forces' (Klaehn 2009: 48, 52).

Interwoven into the power structures of her organisation, Sawyer is unable to overcome her ethnocentric worldview to present an alternative narrative that could have gone beyond the political positioning of the DPRK as a 'a major threat to the security of US citizens' (Lim and Seo 2009: 205). The threat Sawyer presents is not that of a country that possesses nuclear capabilities, rather a country where high-school students and women in beauty salons glance at American fashion magazines without interest. In other words, the threat she presents is of a North Korea that is not a major market for US consumer goods. Sawyer wastes the majority of her report expressing disbelief that the North Koreans could possibly be as happy and patriotic as they seem when they make so little money and have so few possessions. Certainly, ABC's advertisers as well as The Walt Disney Company would like to sell their wares in North Korea, and Sawyer provides anecdotal evidence, such as the appearance of Boston Red Sox and Nike logos on baseball caps worn by people going about their daily lives, to demonstrate that North Koreans actually have consumerist desires for American goods. Sawyer is so fixated on finding evidence that North Koreans would welcome a fullblown US cultural and economic invasion that she misses every opportunity to unpack the North Korean perspective or illuminate North Korean culture, despite the fact that she promises to show 'North Korea as you've never seen it before' (Sawyer 2006). As a consequence, despite the fact that $A B C$ and Sawyer were given the unprecedented opportunity to spend 12 days among the North Korean people and to broadcast live from within their country, North Korea and its people were unable to emerge from the shadows.

\section{Filmography}

Guggenheim, Ralph, and John Lasseter (1995), Toy Story, motion picture, Walt Disney Pictures/Pixar, distributed by Walt Disney Pictures, USA 


\section{A Propaganda Model Case Study}

Sawyer, Diane (2006), ABC Primetime 'North Korea: Inside the Shadows', 2006, DVD, ABC

\section{References}

ABC News (2012), 'Diane Sawyer's Biography', in: ABC World News with Diane Sawyer, 6 February. Online:

http:/ / abcnews.go.com/WN/DianeSawyer/dianesawyersbiography/story?id=9380180\#.UW94D4KGsfE (accessed 18 April 2012)

Abelson, Max (2008), 'Are Eight Bedrooms Enough to Break a Record? 1030 Fifth Duplex Listed for $\$ 47.5 \mathrm{M}^{\prime}$, in: New York Observer, 1 July. Online: http://observer.com/2008/07/are-eight-bedroomsenoughto-break-a-record-1030-fifth-duplex-listed-for-475-m/ (accessed 30 March 2013).

Apartments.com (2012), 'The Star Report: New York', in: Apartments.com. Online:

http:/ / www.apartments.com/starreport/reports/NewYork_DMA.p df (accessed 30 March 2013)

Applegate, Edd (2007), 'The Concepts of "News Balance" and "Objectivity"', in: Public Relations Quarterly, 52 (4), pp. 5-8

Babbie, Earl (2007), 'Qualitative Field Research', in: The Practice of Social Research, international student edition, 11th edition, Belmont CA: Thompson Wadsworth, pp. 285-317

Bowman, Karlyn, and Andrew Rugg (2013), 'Public Opinion on the North Korean Threat: What You May Have Missed in the Polls', in: AEI Ideas, 12 April. Online: http://www.aeiideas.org/2013/04/publicopinion-on-the-north-korean-threat/ (accessed 14 April 2013)

CelebrityDetective (n.d.), 'Diane Sawyer's House Profile Martha's Vineyard-Home Pictures, Rare Facts and Information', in: CelebrityDetective.com. Online: http://www.celebritydetective.com/Celebrity_Homes_DianeSawyer-house-Marthas-Vineyard.html (accessed 30 March 2013)

Choe, Sang-hun (2013), 'In Korea Clip, Only North Sleeps Easy', in: New York Times, 6 February, late edition, p. A4

Choi, Jinbong (2006), 'Framing the National Image of North Korea in the U.S. News Media', paper presented to the meeting of the International Communication Association, Dresden, 19-23 June 
Choi, Jinbong (2010), 'The Representation of North Korean National Image in National Newspapers in the United States', in: Public Relations Review, 36, pp. 392-394

Chung, Mun-young, Justin Lessman, and Meijing Fan (2008), 'Framing the Nuke: How News Media in Six-Party-Talk Countries Framed North Korea's Nuclear Test', paper presented to the meeting of the International Communication Association, Montreal, 22-26 May

Cumings, Bruce (1999), 'Still the American Century', in: Review of International Studies, 25 (5), pp. 271-99

Cumings, Bruce (2004), North Korea: Another Country, New York: The New Press

Cushion, Stephen (2012). 'Introduction', in: Television Journalism, London: Sage, pp. 1-12

Dai, Jia, and Hyun Kideuk (2010), 'Global Risk, Domestic Framing: Coverage of the North Korean Nuclear Test by US, Chinese, and South Korean News Agencies', in: Asian Journal of Communication, 20(3), 299-317

Disney/ABC Television Group (n.d.), 'Corporate and Press Information', in: Disney/ABC Television Group. Online:

http://www.disneyabctv.com/web/index.aspx (accessed 16 June 2012)

Entman, Robert M. (2007), 'Framing Bias: Media in the Distribution of Power', in: Journal of Communication, 57, pp. 163-73

Free Press (n.d.), 'Who Owns the Media?', in: Free Press. Online: http:/ / www.freepress.net/ownership/chart\#charts_tv-radio (accessed 16 June 2012)

Gaines, Steven (2005), 'One Apartment, 75 Years', in: New York Real Estate, 7 November. Online:

http://nymag.com/nymetro/realestate/vu/14943/ (accessed 30 March 2013)

Giroux, Henry A. (2008), Against the Terror of Neoliberalism: Politics Beyond the Age of Greed, Boulder CO: Paradigm Publishers

Hackett, Robert A. (1984), 'Decline of a Paradigm? Bias and Objectivity in New Media Studies', in: Critical Studies in Mass Communication, 1 (3), pp. 229-59

Hanley, Charles J., Choe Sang-Hun, and Martha Mendoza (2001), The Bridge at No Gun Ri, New York: Henry Holt and Company

Harvey, David (2010), A Brief History of Neoliberalism, New York: Oxford 


\section{A Propaganda Model Case Study}

\section{University Press}

Herman, Edward S. (2000), 'The Propaganda Model: A Retrospective', in: Journalism Studies, 1 (1), pp. 101-112

Herman, Edward S., and Noam Chomsky (2002), Manufacturing Consent: The Political Economy of the Mass Media, revised edition, New York: Pantheon Books

IMDb (n.d.). 'North Korea: Inside the Shadows', in: Internet Movie Database (IMDb). Online: http://www.imdb.com/title/tt1350312/ (accessed 16 June 2012)

Jang, Won Yong (2008), 'News as Propaganda in North Korea: An Analysis of News Editorials of the Six-Party Talks, 2003-2007', paper presented to the meeting of the International Communication Association, Montreal, 22-26 May

Khang, Hyoungkoo (2004), 'Framing "Axis of Evil"', paper presented to the meeting of the International Communication Association, New Orleans, 27-31 May

Kim, Jibum, Carl Gershenson, Jaeki Jeong, and Tom W. Smith, (2008), 'How Americans Think About North Korea: 2000-2007', in Public Opinion Quarterly, 72 (4), 804-21

Klaehn, Jeffery (2002). 'A Critical Review and Assessment of Herman and Chomsky's "Propaganda Model"', in: European Journal of Communication, 17 (2), pp. 147-82

Klaehn, Jeffery (2009), 'The Propaganda Model: Theoretical and Methodological Considerations', in: Westminster Papers in Communication and Culture, 6 (2), pp. 43-58

Kristof, Nicholas D. (2003), 'North Korea's Secret,' in: New York Times, 14 January, p. A27

Layne, Christopher, and Benjamin Schwartz (1993), 'American Hegemony: Without an Enemy', in: Foreign Policy, 92, pp. 5-23

Lim, Jeongsub, and Hyunjin Seo (2009), 'Frame Flow Between Government and the News Media and Its Effects on the Public: Framing of North Korea', in: International Journal of Public Opinion Research, 21 (2), pp. 204-23

Lloyd-Roberts, Sue (2010), 'Life Inside the North Korean Bubble', in: BBC News, 1 June. Online:

http://news.bbc.co.uk/2/hi/programmes/newsnight/8701959.stm (accessed 14 April 2013)

Lovdahl, Lynn T. (n.d.) 'Sawyer, Diane: U.S. Broadcast Journalist', in: The 
Museum of Broadcast Communications. Online:

http:// www.museum.tv/ eotvsection.php?entrycode=sawyerdiane (accessed 16 June 2012)

Manyin, Mark E. and Ryun Jun (17 March 2003), 'U.S. Assistance to North Korea,' Report to Congress (Order Code RL31785). Washington, D.C: U.S. State Department. Online: http:// fpc.state.gov/documents/organization/27532.pdf

Mason, Anthony (2004), 'Elite Sources, Journalistic Practice, and the Status Quo', in: Pacific Journalism Review, 13 (1), 107-123

Mullen, Andrew (2009), 'The Propaganda Model After 20 Years: Interview with Edward S. Herman and Noam Chomsky', in: Westminster Papers in Communication and Culture, 6 (2), pp. 12-22

Nakedapartments (n.d.), 'One Bedroom Apartments in $\mathrm{NYC}^{\prime}$, in: Nakedapartments.com. Online:

http://www.nakedapartments.com/nyc/one-bedroom-apartmentsnyc (accessed 30 March 2013)

NK News (2011), 'Select your hairstyle!', in: NK News, 30 October. Online:

http://www.nknews.org/2011/10/select-your-hairstyle/ (accessed 13 April 2013)

NK News (2013), 'Exclusive: Foreigners Now Permitted to Carry Mobile Phones in North Korea', in: NK News, 19 January. Online: http://www.nknews.org/2013/01/exclusive-foreignersnowpermitted-to-carry-mobile-phones-in-north-korea/ (accessed 13 April 2013)

Nylund, Mats (2003), 'Asking Questions, Making Sound-Bites: Research Reports, Interviews and Television News Stories', in: Discourse Studies, (5) 4, pp. 517-533

Schiller, Herbert I. (1989), Culture Inc.: The Corporate Takeover of Public Expression, New York: Oxford University Press

Scott, Anthony Oliver (2004), 'Moral Guidance from Class Clowns', in: New York Times, 15 October, late edition, p. E1

Steinberg, Brian (2010). 'After 2010 Rebound, Broadcast Networks See 2011 Ad Revenue Fall', in: Adage. Online:

http:/ / adage.com/article/media/2010-rebound-broadcast-tv-sees2011-ad-revenuefall/233345/ (assessed 16 June 2012)

US Census Bureau (n.d. a), 'Trade in Goods Korea, North', in: U.S. Census Bureau Foreign Trade. Online http://www.census.gov/foreign-trade/balance/c5790.html 


\section{A Propaganda Model Case Study}

(accessed 17 June 2012)

US Census Bureau (n.d. b), 'Trade in Goods Korea, South,' in: U.S. Census Bureau Foreign Trade. Online: http://www.census.gov/foreigntrade/balance/c5800.html (accessed 17 June 2012)

van Dijk, Teun A. (1991), 'The Interdisciplinary Study of News as Discourse', in: Klaus Bruhn-Jensen, and Nicholas Jankowksi (eds), Handbook of Qualitative Methodologies for Mass Communication Research, London: Routledge, pp. 108-120

Waxman, Sharon (2004), 'The Boys from "South Park" Go to War', in: New York Times, 22 August, late edition, p. 2, 1 